\title{
Contemporary Photography Works of Ruang MES 56: Idea, Interpretation of Information, and Model of Creation
}

\author{
Irwandi \\ Photography Department Faculty of Recorded Media Arts (FSMR) \\ Indonesia Institute of the Arts (ISI) Yogyakarta \\ Email: insinyurwandi@gmail.com
}

\begin{abstract}
Ruang MES 56 is a contemporary photography-based Art Institute in Yogyakarta. This independent art institution has been widely known through its various works in international arts events. The resulting works are not merely personal, but appear to be conceptually charged and based on preproduction information. This article will discuss the discovery of ideas, excavations, and interpretations of information made by artists of Ruang MES 56 in the creation of works. More specifically, this research will dig deeper into what kinds of information artists are searching for in the creation, and how they influence the appearance of the work they produce. The research data will be obtained through interviews and studies of documents owned by selected artists of Ruang MES 56 members. The expected result of this research is the discovery of the created patterns of creation, and can reveal the process of transforming the information that has been collected into the form artworks.
\end{abstract}

Keywords: information, artwork, ruang MES 56, contemporary photography

\section{INTRODUCTION}

MES 56 is an institute, a collective space of contemporary art based on photography, located in Yogyakarta. This institute consists of a number of artists, managers who function as studios, learning environment, place to gather, and residence/residency. Ruang MES 56 is an artist collective working cooperatively with their communities and networks to manage a house for studio, education, playground and a place to live in. Formed in 2002 with self-funding, this community focusing on the development of photography and contemporary art crossing over with other disciplines in critical and contextual works (http://mes56.com/mes-56/). In a video published by Foam Photography Museum Amsterdam, Foam 3h: Foam X Ruang MES 56 (2017) Wimo Ambala Bayang tells that MES 56 also focuses on interdisciplinary, critical, contextual, and networking photography. This already indicates that MES 56 can be said to be different from photography communities in general. There is a certainty that the 
medium of photography chosen by the agency is used with unusual approaches. Cross-discipline, critical, contextual, and networking as stated by Bayang, are the key to how MES 56 behaves, responds, and displays photography.

Another thing that is also mentioned is networking. MES 56 positioned networking as important in carrying out its mission. Furthermore, according to Angki Purbandono in an interview video titled MES 56 released by IndoArt Now, (2016), MES 56 has three principal definitions of networking or colleagues used as a reference, namely: 1) educational networking; 2) institutions having the same working character, independent in national and international coverage; and 3) art markets, whether in the form of exhibitions, art projects, or residencies.

\section{MATERIAL AND METHOD}

MES 56 with a vision-mission choice and its network must necessarily adapt and run the consequences. It is these missions and networks that allegedly influence the ideas, interpretations of information or research/processing of pre-creation information, and creation models to the form of work produced. In more detail, the questions to be answered in this article are: 1) what kind of ideas tend to be chosen by MES 56 artists?; 2) how do artists of MES 56 do initial research/information processing on which to base their creation?; 3) how is the influence of the information gained on the form of the work produced?

Through this article, these questions will be answered. The methods used in writing this article include interviews, literature studies, and documents. The data obtained then presented in the form of description and analysis on the creation cases made by a number of artists in MES 56. Through this study, it is expected to demonstrate the important role of research and discover the methods of creation that can be useful in the discourse of practice-based research, especially in the field of photography art.

\section{MES 56 and Photography: Overview}

In the beginning, in 1996 MES 56 was not an official art institution. At that time, MES (originally without 56) was the name of a rented house that was once a MES in Indonesian meaning temporary living residence or as a guest residence in the military for the residence of an unmarried officer belonging to AURI, located on Kolonel Sugiyono 56 Street. The location became a place to gather and live for a number of photography students, Photography Department Faculty of Recorded Media Arts (Fakultas Seni Media Rekam) Indonesia Institute of the Arts (ISI) Yogyakarta who had the same point of view, association, and interest in the work of photography. In those days, the uniqueness of the work of the members of MES 
was motivated by the desire to create different works and influenced by their academic background on campus, where they received a course on Photographic Expression taught by Subroto Sm and Risman Marah. They were driven to be 'crazy', crazy in the experimentation of photography (Isabella in Widhi, 2015:117).

Negative films were often targeted for exploration and experimentation of members of MES 56, some of were them Angki Purbandono, Wimo Ambala Bayang, and Iskandar. According to Akiq AW, "the early generations of MES 56 tried to follow the visuals development shown in magazines from abroad. While it was still oriented towards painting, we had not realized that photography itself was very political" (interview, July $24^{\text {th }}, 2018$ ). As time passes, digital photography begins to popularize. The resulting photo displays with negative experiments are now easily produced with the photography software. Rangga Purbaya, one of the earliest members of MES 56, said "the looks of the works in the past which seemed very skillfull and needed knowledge, in the digital age becomes nothing" (interview, July 25, 2018). This became a challenge of MES 56. Collectively they began to think of the direction of the working of MES 56 in the future.

In 2004, through the Holiday MES 56 project increasingly carrying conceptual photography heavily. In general, conceptual photos are photographs that cannot be included in traditional photo categories, photographs that no longer serve objective, documentary, and pictorial representation, but rather place photography with all its properties as a means of articulating ideas, social views, issues of life that exist outside the media of photography itself (see Molon in Warren, 2006: 304-306). There is a significant change in the style of the work of MES 56 in 4-5 years of age. The works of technical-visual experimentation through the processing of negative films begin to be abandoned. After that, MES 56 emphasized the collectivity in working through the works of conceptual photography. Nevertheless, since its inception, MES 56 has had one characteristic in its employment practice: emphasizing ideas, concepts, life issues in the themes of their work, both in the works of technical-visual experimentation and in their conceptual works. To create photographic works that emphasize ideas, concepts, life issues, the research process, the deepening of ideas are familiar to members of MES 56. The research, the deepening of ideas, and the concepts of work are certainly closely related to information gathering, information interpretation. Both of these are the focus of this article's discussion, especially on how the process and its effects on the way they create and present their works. 


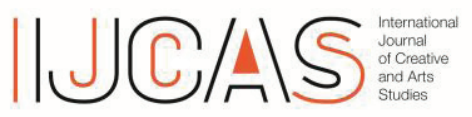

Volume 6 Number 1, June 2019 | p-ISSN 2339-191X, e-ISSN 2406-9760

\section{RESULT}

\section{Alhamdulillah, We Made It}

One of MES 56's collective works of photography to be discussed is a work entitled 'Alhamdulillah, We Made It'. This work is the Comission Works achieved by MES 56 in 2015 which was first shown at Adelaide Festival Centers Australia in the OzAsia Festival event, September 24 - October 4, 2015 (OzAsia Festival Catalog 2015:29). The search of this 'Alhamdulillah' work, comes from Rangga Purbaya's information which was one of the intensely involved in this project through an interview conducted on July 25, 2018.

"At that time, we got an invitation to exhibit there, but the committee did not set a specific theme for the works to be displayed. We were asked to propose a theme. As a contemporary art-based art institution, MES 56 is concerned with social and life issues. Based on that, this work raises the issue of refugees who want to become immigrants to Australia, which at that time is being warmly reported. Indonesia at that time became the transit of immigrants who want to become permanent citizens of Australia. For MES 56 itself, the problem of immigrants is not just a matter of Indonesia and Australia alone, this has become a regional problem."

Photoworks 'Alhamdulillah, We Made It' presented at the OzAsia Festival in the form of photo prints and folding books featuring photographs of asylum seekers stranded in Indonesia. There were different ways in which MES 56 displayed the asylum seekers who were being accommodated by the Jesuit Refugee Service (JRS) who then owns an office in Yogyakarta. Asylum seekers were photographed in a state of activity at a shelter: being at work, cooking, and posing in front of the camera. The human subjects were photographed by way of cuts, so the photographs featured the white silhouettes of the removed immigrants. In other photographs, the results of previous photographs had been cut in the collage digitally in other photographs of the mood of places in Australia. The photographs were given a brief caption containing the name of the subject, country of origin, date of birth, duration of being refugees, and personal expectations.

'Alhamdulillah', as one of the words in the title of the work is derived from Arabic which means Praise (be) to Allah, which is also a word that describes gratitude, pleasure of a person over a condition or achievement that matches or exceeds what is expected. Thus, the title seemed to convey the gratefulness of the asylum seekers because it has succeeded in realizing their wishes, namely a comfortable and ideal life. In the end of the spectator would realize and empathize that the title is actually an irony and satire. Because, in fact the achievement of the asylum seekers was only achieved virtually, through the medium of photography. 


\section{DISCUSSION}

The work of 'Alhamdulillah' is an example of collective photographic works made by MES 56 with various considerations. The members involved in the production of the work did many things before the process of making the work done. There was a research process undertaken, there were discoveries, which were then combined with their intuitive process as human beings and artists. The text in this section comes from interviews with Rangga Purbaya, one of the active members of this collective project, dated July 25, 2018.

When the invitations for the exhibition came, and they were asked to propose a theme of work, the first process was to search and to gather information on issues being discussed at a global level. Various information, both from the internet and the media around them used as material of thought and reflection. In the case of 'Alhamdulillah' works, artistic decisions were not directly defined.

There was an initial discussion conducted by members of this art project continuously. One of the important moments in the process of searching for ideas and themes of their work was when one of the member of MES 56 involved in the project found an anti illegal immigrant poster released by the Australian government. The poster was affixed to a typical Padang restaurant located on Parangtritis street, not far from the MES 56 studio. The moment struck them, and encouraged them to seek further information. Until one day they also found posters of invitations to British whites to migrate to Australia after World War II.

In 2015, immigrant problems in Indonesia and Australia were being discussed, one of which was the case of the return of illegal immigrants who had arrived in Australia with vessels directed to Indonesia (https://nasional.tempo.co/read/553979/kapal-wah-imigran-menlu-protes-keaustralia). "The ships were then stranded on the south coast of Indonesia. From that we know that this issue is a big issue, a humanitarian issue, not just an Australian problem" said Purbaya. Such stories annoyed the artists' sense of humanity in this art project, and in the end they decided to raise the issue of asylum seekers for their work on the 'Alhamdulillah' art project. 

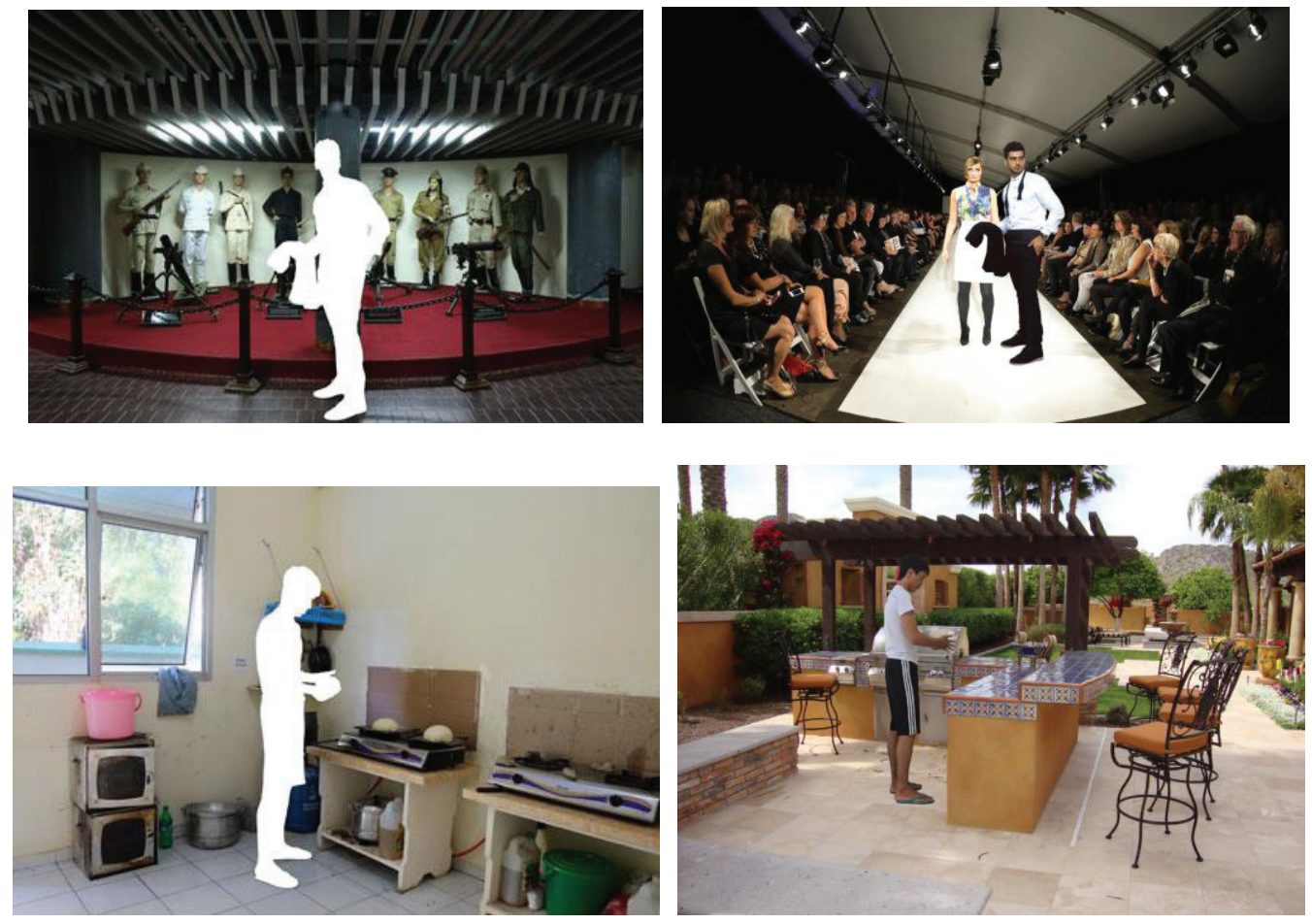

Fig. 1. Some of the works in the series 'Alhamdulillah We Made It'. The left picture is taken in Yogyakarta, the right photo is cultivated with a catwalk 'location' in Australia.

(Source: MES 56 Collection)

The advancement of information technology, especially the internet, greatly helps artists in finding the necessary information to strengthen the foundations of the concept of creation. The process of extracting information done through the internet lead them to find the appropriate stakeholders. In the case of this work, MES 56 traced information about organizations dealing with refugees. Based on these search results, MES 56 then studied and visited JRS under the International Organization of Migration (IOM). JRS was headquartered in Yogyakarta. "We came to JRS to seek further refugee issues, and we view JRS as a relevant institution. To find out the refugee problem, we are given a one day workshop, in order to understand the refugee problem, and so what we do in the refugee place do not become a new problem.'

A further step by MES 56 after gaining access to asylum seekers was to communicate the intent and purpose of their program. Persuasion attempts were made to build trust. As stated by Rangga Purbaya,

"In fact they (the asylum seekers) are well aware that they are vulnerable to be utilized therefore we introduce our institutions, who we are, our intentions. We assure you that what we are doing is to send a message there (Australia), that this issue is a common problem. We can 
say we are accepted there, we can trust, and establish good relations with asylum seekers and JRS."

Another problem arose in the Adelaide Festival, as this issue was a hot and sensitive issue in Australia. There had been a disagreement over the issue raised, forcing the Adelaide director of the festival to come to Jogja, to object to issues raised by MES 56.

"There was a rejection but we reasoned that what we were doing was our responsibility as an artist, to bring about an important issue. We do not question/seek political correctness of Australian policy at the time, but feeling that the policy has an impact on the region, so it is important to be pushed there. About artistic/photo presentation is the thing done while progressing/last done. After interacting with asylum seekers in the refugee camp, MES 56 then thinks about what this work will be. What should we do with the materials? We finally try to subvert the concept of asylum. Through the use of photographic technology, photographs of asylum seekers are cut and then pasted into Australian background photos. Photographic asylum seekers have achieved their goals. How to display photos in this project is an appropriation of our previous Holiday project but with different concepts, content, and contexts. The Holiday project itself was created in 2004."

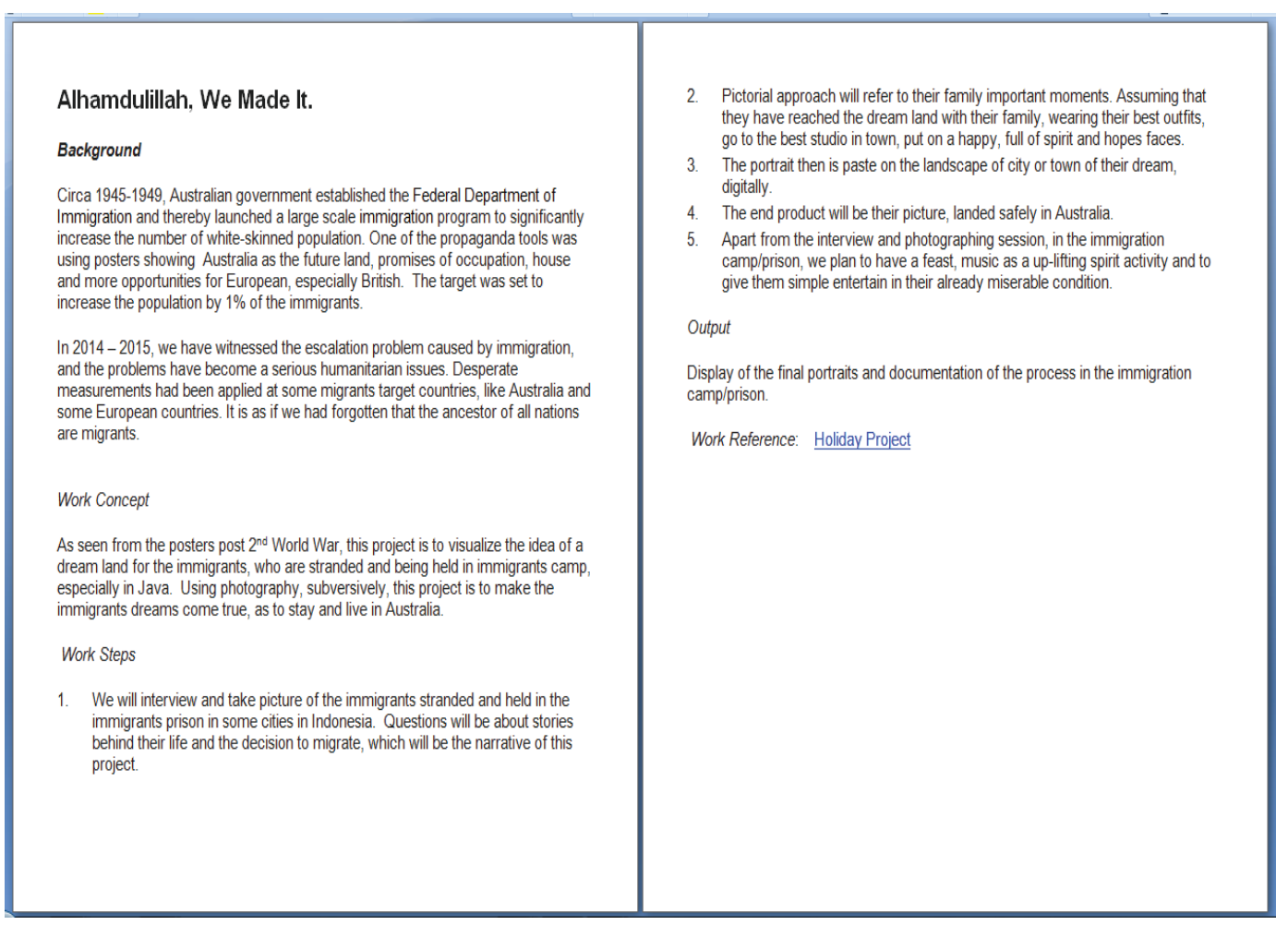




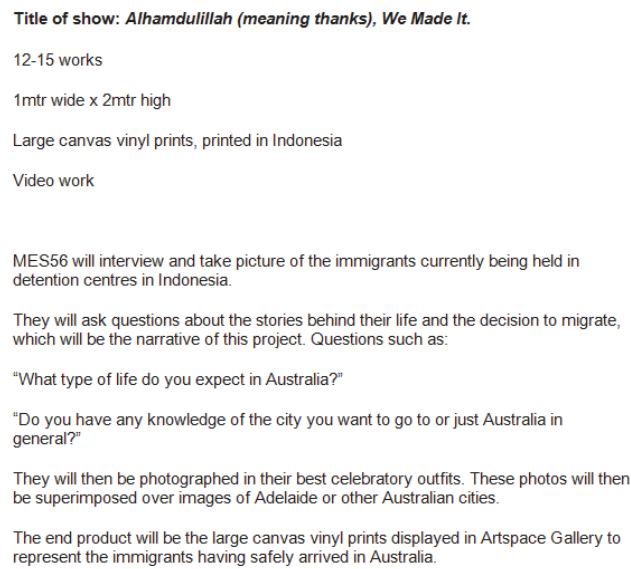

Fig. 2. Concept and Design of the exhibition series of works of 'Alhamdulillah, We Made It'. (Source: MES 56 archive)

The MES 56 opt to select the way the work appears as it has been done based on the messaging, place, and customs of MES 56. The message becomes an important thing to deliver, therefore MES 56 chose the most easily understood photo style.

"We need something simple and straightforwardly understood, we need a strategy for delivering messages and MES Having a habit of choosing the simplest way. This method is also chosen because these photos will be displayed at the festival event. This work is shown to the public."

Finally the 'Alhamdulillah' project was done. MES 56 then resolved administrative/legal affairs to asylum seekers. It is important for artists that anyone involved in a collective art project was on record and formal. Not just verbally. MES 56 makes a model release to make sure that what is displayed is subject to the approval of the subject in it.

\section{Research: Information, Interpretation, and Presentation: A Conclusion}

An overview of works collected by MES 56 collectively and by individual members may illustrate how the interrelation between information outside the work, the interpretation of the artist to the information, and its effect on the presentation of the work applies in a process of art by MES 56 and the its members. Information outside of works in creation cases described in this paper is broadly understood. How to search information and forms of information gathered 
are done in various ways, in accordance with the ideas and context of creation. Aspects of art, in this case creativity, intuition, and delinquency think as an artist cannot be forgotten and even greatly affect the way, type, and place of information which will be collected.

Presentation of the work, in the sense of style and subjects featured in the work interacts with issues raised, artist's memory, art intuition, artistic purposes of the work, and information gained in the process of creation research. The shape and direction of interaction of these aspects is very flexible and tentative.

In the case of the work of 'Alhamdulillah, We Made It', it appears that the deepening of information about immigrants and the projection of the wishes of immigrants becomes the main information to be further processed. Instead of displaying the hope and suffering of asylum seekers with verbal photographs, subversive ways of photography were selected, with consideration of who the audience is and the readability of the message to be conveyed. That is, information about who the subject is being photographed and who the subject is looking at becomes an important consideration, with its ideological, political, and cultural implications. Critical discourses of photographic media were used as approaches, coupled with the intuition and different perspectives of MES 56 on the medium of photography. Photography here is used to express virtual displacement, adding to the rebuttal of the temporary and objectivity of photography.

The following table illustrates the ideas, research, and works of MES 56:

\begin{tabular}{|c|c|c|c|}
\hline No. & Idea/Issues & $\begin{array}{l}\text { Research \& } \\
\text { Information }\end{array}$ & Interpretation/art forms \\
\hline 1 & Live experience. & $\begin{array}{l}\text { Literation, artefacts, } \\
\text { and their meaning. }\end{array}$ & \multirow{4}{*}{$\begin{array}{l}\text { 1. Stimulation } \\
\text { idea/memory through } \\
\text { representative forms. } \\
\text { 2. Collage of memory. } \\
\text { 3. Interactive. } \\
\text { 4. Non-conventional. } \\
\text { 5. Witt, delinquency of } \\
\text { thoughts. }\end{array}$} \\
\hline 2 & $\begin{array}{l}\text { Popular practices/Cultural } \\
\text { Practices. }\end{array}$ & \multirow{2}{*}{$\begin{array}{l}\text { Literation, observation, } \\
\text { recording, } \\
\text { participation. }\end{array}$} & \\
\hline 4 & Misery \& Regional Issues. & & \\
\hline 5 & Policy of Social Politics. & $\begin{array}{l}\text { Stimulus, document } \\
\text { study, and artefacts. }\end{array}$ & \\
\hline
\end{tabular}

Table of ideas, research, and art forms of MES 56's works (Irwandi)

The examples of creation cases presented in this paper, there is a tendency for artists to treat the information they get. First, the information gained is the material of thought and then determines the issues to be presented in the work; second, the information around the creator is interpreted to be presented in ways that meet the artistic criteria of a work of art, the artist already has his or her personal style, in that way the artist then speaks; third, the creation of the work 
begins with intuition, the creative idea of the internalization of the artist's experience which is then poured in the form of the work, the information gathered is reinforcing the ideas that have emerged. Fourth, photography is seen as a processed entity differently, in accordance with the conditions and situation of pre-creation information, hence, traditional photographic conventions are abandoned. Behind the importance of information in employment, the contexts, goals, and habits of artists in making works determine the direction of how information is treated.

\section{REFERENCES}

Dominic Molon "Conceptual Photography", Lynne Warren. 2006. Encyclopedia of twentieth-century photography, Routledge, New York.

http://mes56.com/foam-x-ruang-mes-56/

http://www. mes56.com/mes-56/

https://nasional.tempo.co/read/553979/kapal-wah-imigran-menlu-protes-keaustralia (13 Februari 2014)

https://subbacultcha.nl/event/foam-X-ruang-mes-56-yudha-kusuma-putera-andriwilliam/

https://www.foam.org/museum/programme/foam-X-ruang-mes-56

https://www.youtube.com/watch?v=5eD9Md9KazE\&t=18s, video Mes 56, (2016), Indoartnow.

https://www.youtube.com/watch?v=GRGb2W_ACNo\&t=89s, Video Foam Fotografiemuseum Amsterdam, Foam 3h: Foam X Ruang Mes 56, (2017). Isabella, Brigitta, "Cerita Sebuah Ruang dan Orang-orang yang Hidup di Dalamnya", Agung Nugroho Widhi (ed.). 2015. Cerita Sebuah Ruang, Menghidupi Ekspektasi: Membaca Fotografi Kontemporer Melalui Praktik Ruang Mes 56. Yogyakarta: IndoArt Now.

OzAsia Festival Catalog. 2015. Adelaide Festival Centre, Adelaide.

\section{Informant}

Akiq AW, 41 years old, Artist, Member MES 56, lives in Yogyakarta. Angki Purbandono, 47 years old, Artist, Founder of MES 56, lives in Yogyakarta. Rangga Purbaya, 42 years old, Artist, Member of MES 56, lives in Yogyakarta. Wimo Ambala Bayang, 41 years old, Artist, co-founder MES 56, lives in Yogyakarta. 